\title{
How Do Auditors Increase Substantially Firm Value?
}

\author{
Ya-Fang Wang ${ }^{1} \&$ Yu-Ting Huang ${ }^{2}$ \\ ${ }^{1}$ Department of Accounting, Providence University, Taichung City, Taiwan \\ ${ }^{2}$ Ph. D. Program in Business, Chung Yuan Christian University, Chung Li City, Taiwan \\ Correspondence: Ya-Fang Wang, Department of Accounting, Providence University, Taichung City, Taiwan. Tel: \\ 886-4-2632-8001 ext. 13216. E-mail: yfwang2@pu.edu.tw
}

Received: July 15, 2014

doi:10.5539/ijef.v6n10p76

\author{
Accepted: July 24, 2014 \\ Online Published: September 25, 2014 \\ URL: http://dx.doi.org/10.5539/ijef.v6n10p76
}

\begin{abstract}
This study used Tobin's Q to examine the relationship between various types of auditors (e.g., industry expert, supply chain auditor) and market participants in order to determine the effects on firm value. Our results indicate that market participants highly value Big 4 supply chain auditors with industry experience and that these impressions are extended to their evaluation of their clients. We also found that only in the subsample of long-term auditor-client relationships were Big 4 supply chain auditor with industry experiences is auditors associated with higher firm value. This is consistent with previous literature indicating that the tenure of auditors does not affect audit quality (Myers, Myers, \& Skinner, 2007; Myers, Myers, \& Omer, 2003). The inclusion of different supply chain streams revealed that up-stream supply chain auditors are more likely than middle and down-stream supply chain auditors to receive favorable reactions from market participants. This is an indication that market participants are impressed by the specific expertise and knowledge of these professionals.
\end{abstract}

Keywords: supply chain auditor, audit quality, firm value, firm performance

\section{Introduction}

By conveying accurate information about the performance of firms, auditors can have a significantly positive effect on audit quality. The selection of auditor therefore has a powerful effect on the value of the firm; however, most previous studies on the role of auditors have focused on the relationship between audit quality and financial reporting quality. Very little objective evidence has been provided to clarify the means by which auditors affect the value of firms. This study investigated various auditor characteristics to determine whether auditors affect the economic performance of clients and the means by which this manifests.

Auditors play an important role in the areas of internal control and financial reporting (Dang, 2004). Previous studies have examined the role of auditors in improving the quality of financial reporting (Chin \& Chi, 2009; Francis, LaFond, Olsson, \& Schipper, 2005; Owhoso, Messier, \& Lynch, 2002; Solomon, Shields, \& Whittington, 1999; Becker, DeFond, Jiambalvo, \& Subramanyam, 1998; Palmrose, 1988; Teoh \& Wong, 1993). Numerous methods have been devised to facilitate the measurement of audit quality, using firm size, financial restatements, the specialization of auditors, and the length of auditor-client relationships as proxies for audit quality. However, these studies have returned varied results. For example, some studies (Francis, 2004; Francis, Maydew, \& Sparks, 1999; Becker et al., 1998) claimed that large auditing firms are more strongly associated with strong financial performance. However, Kabir, Sharma, Islam, and Salat (2010) and Jeong and Rho (2004) were unable to find evidence linking the size of the auditing firm and the financial performance of the firms they represent. A number of studies (Reichelt \& Wang, 2010; Knechel, Naiker, \& Pacheko, 2007; Balsam, Krishnan, \& Yang, 2003; Krishnan, 2003; Gramling \& Stone, 2001) have claimed that the specialization of auditors is associated with firm performance and that long-term auditor-client relationships enhance client-specific knowledge (Ghosh \& Moon, 2005; Mansi, Maxwell, \& Miller, 2004; Myers et al., 2003; Johnstone, Bedard, \& Biggs, 2002); however, many other studies (Davis, Soo, \& Trompeter, 2009; Gul, Fung, \& Jaggi, 2009; Boone, Khurana, \& Raman, 2008) have published findings that contradict these claims.

These mixed results can be attributed to the use of clients' market share to measure big auditing firms and industry specialization. These studies disregarded the fact that auditors can be classified according to industry-specific knowledge (e.g., supply chain knowledge of up-stream firms). This study re-examined and extended the empirical results obtained in previous studies, focusing solely on electronics companies because of 
their importance to the economic development of Taiwan. We adopted supply chain knowledge as the distinguishing characteristic of auditors. This study differs from previous works in its examination of the relationship between auditors specializing in supply chain knowledge and firm value. Our results show that the selection of supply chain auditors can significantly increase the value of a firm; however, it appears that only supply chain auditors from the Big 4 produce these effects. This is an indication that market participants tend to be predisposed toward Big 4 supply chain auditors. This is perhaps because their experience is believed to enhance auditing efficiency and the quality of financial reporting. Second, we extended the work performed in previous studies (Myers et al., 2007; Myers et al., 2003) by taking the auditor-client relationship into account in our analysis and discovered that long-term auditor-client relationships are positively associated with higher firm value. Furthermore, this relationship was more pronounced in up-stream than in middle and down-stream companies, possibly due to their perceived expertise and specialized knowledge.

\section{Research Methodology}

\subsection{Data Sources}

Our sample was selected from the electronic companies listed on the Taiwan Stock Exchange over the period 2002-2010 and included in the Taiwan Economic Journal (TEJ) database. Information on supply chains (e.g., supply chain auditors and supply chain streams) was hand-collected from the database of the Market Observation Post System (MOPS) and the Future of the Electronics Industry, published by Taiwan Changhong Inc. Financial data was obtained from the TEJ annual files. Cases that did not disclose information related to suppliers or financial data were excluded.

\subsection{Model Specification}

A research model was constructed to examine whether the selection of supply chain auditor is associated with firm value. The research model (1) is as follows:

$$
\begin{gathered}
\text { TOBINSQ }_{i, t}=\alpha_{0}+\alpha_{1} S C P A_{i, t}+\alpha_{2} G R O W T H_{i, t}+\alpha_{3} S I Z E_{i, t}+\alpha_{4} L E V_{i, t}+\alpha_{5} S R D_{i, t} \\
+\alpha_{6} A G E_{i, t}+\alpha_{7} F C F_{i, t}+\alpha_{8} R D_{i, t}+\varepsilon_{i, t}
\end{gathered}
$$

where TOBINSQ is equal to the market value of equity plus total debt divided by total assets; SCPA is equal to 1 if the company hires a supply chain auditor and otherwise 0; GROWTH is the percentage increase in sales over one year; SIZE is the natural log of total assets; $L E V$ equals total long-term liabilities divided by total assets; $S R D$ equals one minus the long-term investments plus fixed assets to total assets; $A G E$ equals the natural log of one plus the number of years elapsed since the year of incorporation; $F C F$ equals cash flow from operations minus cash dividends divided by total assets; $R D$ equals research and development expenses divided by sales; and $Y E A R$ is the fiscal year dummy.

\section{Results and Analysis}

Our final sample comprised 1,081 firms from 2002 to 2010. Table 1 presents the descriptive statistics for the variables used in the models, partitioned into three subsamples: total number of firms in sample $(\mathrm{n}=1,081)$, firms that hired supply chain auditors $(n=264)$, and companies that did not hire supply chain auditors $(n=817)$. As expected, the mean (median) of TOBINSQ for the supply chain auditor subsample is larger than that for the non-supply chain auditor subsample. This suggests that market participants are predisposed to companies that hire supply chain auditors. Firms with a supply chain auditor have a larger size (SIZE), lower debt ratio (LEV), higher operating cash flow $(F C F)$, and longer established time $(A G E)$ than companies that did not hire supply chain auditors.

Table 2 presents the Pearson correlation matrix for the research variables in Eq. (1). Most of the explanatory variables are not significantly correlated with one another. Correlations between firm value (TOBINSQ) and the hiring of a supply chain auditor (SCPA) are in the predicted direction and statistically significant at the 0.05 level. Additionally, TOBINSQ is correlated with GROWTH (0.076), SIZE (0.090), LEV (-0.112), SRD (0.162), AGE (0.096), and $F C F(0.113)$, suggesting that larger companies, those presenting better performance, lower leverage, more short-term investments, longer established time, and greater operating cash flow are associated with greater value.

Table 3 lists the correlation between firm value and the selection of auditor. As shown in column (1), the coefficient of SCPA is significantly positive at the 0.05 significance level, indicating that the selection of a supply chain auditor is associated with firm value. To determine the effects of the size of the auditing firm on the relationship between supply chain auditors and firm value, we partitioned the sample into two subsamples: firms that hired a Big 4 auditing firm and those that did not. Results show that the SCPA coefficient was significantly 
positive only in the Big 4 subsample, indicating that only Big 4 supply chain auditors are associated with increased firm value. In addition, the coefficients of the control variables (GROWTH, SIZE, LEV, SRD, FCF, RD) indicate that companies with better sales growth, larger company size, lower leverage, more short-term investments or R\&D investments, and higher operating cash flow are associated with higher firm value.

Table 1. Descriptive statistics

\begin{tabular}{|c|c|c|c|c|c|c|c|c|c|}
\hline \multirow[b]{2}{*}{ Variables $^{\text {a }}$} & \multicolumn{3}{|c|}{ Total sample $(\mathrm{n}=1,081)$} & \multicolumn{3}{|c|}{ Supply chain auditor ${ }^{\mathrm{b}}(\mathrm{n}=264)$} & \multicolumn{3}{|c|}{ Non-Supply chain auditor $(\mathrm{n}=817)$} \\
\hline & Mean & Median & Std. Dev & Mean & Median & Std. Dev & Mean & Median & Std. Dev \\
\hline TOBINSQ & 1.3737 & 1.1467 & 0.8714 & 1.5286 & 1.1555 & 1.2192 & 1.3237 & 1.1436 & 0.7180 \\
\hline GROWTH & 0.1525 & 0.0874 & 0.7113 & 0.1410 & 0.1330 & 0.3664 & 0.1562 & 0.0789 & 0.7914 \\
\hline SIZE & 21.6717 & 21.4996 & 1.2658 & 22.1346 & 21.9668 & 1.4374 & 21.5222 & 21.4133 & 1.1675 \\
\hline$L E V$ & 0.0748 & 0.0316 & 0.0948 & 0.0638 & 0.0046 & 0.0912 & 0.0783 & 0.0380 & 0.0957 \\
\hline$S R D$ & 0.6025 & 0.6058 & 0.2009 & 0.5950 & 0.5901 & 0.2023 & 0.6050 & 0.6104 & 0.2006 \\
\hline$A G E$ & 1.4852 & 1.6094 & 0.8526 & 1.5573 & 1.7918 & 0.8713 & 1.4619 & 1.6094 & 0.8457 \\
\hline$F C F$ & 0.0457 & 0.0427 & 0.1006 & 0.0543 & 0.5010 & 0.1019 & 0.0429 & 0.0414 & 1.0001 \\
\hline$R D$ & 0.0564 & 0.0237 & 0.1402 & 0.0548 & 0.0224 & 0.2147 & 0.0569 & 0.0244 & 0.1056 \\
\hline
\end{tabular}

${ }^{a}$ The definitions of the variables reported in this table are: $T O B I N S Q=$ the market value of equity plus total debt divided by total assets; GROWTH = one-year percentage increase in sales; SIZE = natural logarithm of total assets; $L E V=$ total long-term liabilities divided by total assets; $S R D=$ one minus the long-term investments plus fixed assets to total assets; $A G E=$ the natural log of one plus the number of years elapsed since the year of incorporation; $F C F=$ cash flow from operations minus cash dividends divided by total assets; $R D=$ research and development expense divided by sales.

${ }^{\mathrm{b}}$ Many suppliers and their major customers share a common audit firm or even common auditors in endorsing financial statement.

Table 2. Correlation matrix ${ }^{\mathrm{b}}$

\begin{tabular}{lcclccccc}
\hline \multicolumn{1}{c}{ Variables $^{\text {a }}$} & TOBINSQ & SCPA & GROWTH & SIZE & LEV & SRD & AGE & $F C F$ \\
\hline SCPA & $0.101^{*}$ & & & & & & & \\
GROWTH & $0.076^{*}$ & -0.009 & & & & & & \\
SIZE & $0.090^{*}$ & $0.208^{*}$ & -0.033 & & & & & \\
LEV & $-0.112^{*}$ & $-0.066^{*}$ & $0.108^{*}$ & $0.151^{*}$ & & & & \\
SRD & $0.162^{*}$ & -0.021 & 0.033 & $-0.399^{*}$ & $-0.289^{*}$ & & & \\
$A G E$ & $0.096^{*}$ & 0.048 & $-0.167^{*}$ & $0.317^{*}$ & -0.025 & $-0.226^{*}$ & & \\
$F C F$ & $0.113^{*}$ & 0.049 & -0.019 & $0.145^{*}$ & -0.007 & -0.058 & 0.052 & \\
$R D$ & 0.048 & -0.006 & $0.183^{*}$ & $-0.099^{*}$ & 0.011 & -0.023 & -0.001 & $-0.099^{*}$ \\
\hline
\end{tabular}

${ }^{\text {a }}$ The definitions of the variables reported in this table are: $T O B I N S Q=$ the market value of equity plus total debt divided by total assets; $S C P A=1$ if a company hires supply chain auditors, else $0 ; G R O W T H=$ one-year percentage increase in sales; SIZE = natural logarithm of total assets; $L E V=$ total long-term liabilities divided by total assets; $S R D=$ one minus the long-term investments plus fixed assets to total assets; $A G E=$ the natural $\log$ of one plus the number of years elapsed since the year of incorporation; $F C F=$ cash flow from operations minus cash dividends divided by total assets; $R D=$ research and development expense divided by sales.

${ }^{\mathrm{b}}$ Pearson correlations in the lower diagonal. * Indicates significance at the 5 percent level.

Table 3. Supply chain auditor and firm value: Big 4 vs. Non-Big 4

\begin{tabular}{|c|c|c|c|c|c|c|c|}
\hline \multirow{3}{*}{$\frac{\text { Variables }^{\text {a }}}{\text { CONSTANT }}$} & \multirow{3}{*}{ Pred. Sign } & \multirow{2}{*}{\multicolumn{2}{|c|}{$\frac{\text { Total sample }}{\text { Coefficient } t \text {-value }^{\mathrm{b}}}$}} & \multirow{2}{*}{\multicolumn{2}{|c|}{$\frac{\operatorname{Big} 4^{\mathrm{c}}}{\text { Coefficient } t \text {-value }^{\mathrm{b}}}$}} & \multirow{2}{*}{\multicolumn{2}{|c|}{$\frac{\text { Non-Big } 4}{\text { Coefficient } t \text {-value }^{\mathrm{b}}}$}} \\
\hline & & & & & & & \\
\hline & & -1.8472 & $-3.58 * * *$ & -2.0965 & $-3.76 * * *$ & 6.2033 & $3.76^{* * *}$ \\
\hline$S C P A$ & + & 0.1235 & $2.13 * *$ & 0.1144 & $1.98^{* *}$ & -0.2405 & -0.32 \\
\hline GROWTH & + & 0.1028 & $2.88 * * *$ & 0.4759 & $5.98 * * *$ & -0.0105 & -0.22 \\
\hline SIZE & $?$ & 0.1048 & $4.63 * * *$ & 0.1106 & $4.49 * * *$ & -0.2574 & $-3.45^{* * *}$ \\
\hline$L E V$ & - & -0.4283 & $-1.56^{*}$ & -0.3923 & $-1.31^{*}$ & -0.3753 & -0.57 \\
\hline$S R D$ & + & 0.9801 & $7.11 * * *$ & 0.9809 & $6.54 * * *$ & 0.3569 & 1.10 \\
\hline$A G E$ & $?$ & 0.0120 & 0.33 & 0.0250 & 0.65 & 0.3411 & $2.49^{* *}$ \\
\hline$F C F$ & + & 1.0417 & $4.24 * * *$ & 1.1626 & $4.46^{* * *}$ & -0.5251 & -0.80 \\
\hline$R D$ & + & 0.4523 & $2.54 * * *$ & 0.5506 & $3.02 * * *$ & -0.0932 & -0.14 \\
\hline
\end{tabular}




\begin{tabular}{lccc}
\hline YEAR & Included & Included & Included \\
Adj. $R^{2}$ & $17.12 \%$ & $21.50 \%$ & $14.20 \%$ \\
$\mathrm{n}$ & 1081 & 959 & 122 \\
\hline
\end{tabular}

${ }^{\mathrm{a}}$ The definitions of the variables reported in this table are: $S C P A=1$ if a company hires supply chain auditors, else 0; GROWTH= one-year percentage increase in sales; $S I Z E=$ natural logarithm of total assets; $L E V=$ total long-term liabilities divided by total assets; $S R D=$ one minus the long-term investments plus fixed assets to total assets; $A G E=$ the natural $\log$ of one plus the number of years elapsed since the year of incorporation; $F C F=$ cash flow from operations minus cash dividends divided by total assets; $R D=$ research and development expense divided by sales.; YEAR = fiscal year dummies.

${ }^{\mathrm{b}}$ Asterisks $*, * *, * *$ indicate two-tailed significance at the $0.10,0.05$, and 0.01 levels, respectively.

${ }^{\mathrm{c}}$ In June 2003, Deloitte and Touche has merged into Deloitte \& Touche accounting firms, and audit market change from big five accounting firms to big four accounting firms which distinguish from Deloitte Touche, Ernst \& Young, KPMG, and PricewaterhouseCoopers

As discussed above, our empirical results provide evidence to support the claim that when companies hire Big 4 supply chain auditors, they are more likely to receive a favorable reaction from market participants, which leads to an increase in firm value. We focused on firms that hired Big 4 supply chain auditors to determine whether specialization in the auditing industry affects the relationship between the choice of supply chain auditor and firm value. Table 4 provides the results of partitioning the sample of firms that hired Big 4 supply chain auditors into a group comprising those considered industry experts and a group comprising those not considered industry experts. We found that $S C P A$ was significant $(\mathrm{p}<0.01)$ only in the group of industry experts, which is consistent with our hypothesis that specialization in the auditing industry is important to market participants and the users of financial statements due to a belief that the experience of auditors improves the quality of financial reporting with a subsequent positive effect on firm value.

Previous studies (Myers et al., 2007; Myers et al., 2003) have indicated that audit quality improves with the tenure of the auditor. This suggests that a long-term auditor-client relationship helps auditors to gain vital information specific to the client firm, which has a positive effect on the quality of the resulting auditing reports and thereby enhances the value of the company. Table 5 indicates that the SCPA coefficient is only significantly positive (at least at the $1 \%$ significance level) in the group that includes auditors with longer tenure, which suggests that market participants are of the opinion that a long-term auditor-client relationship is positively associated with higher firm value.

Table 4. Big 4 supply chain auditor and firm value: industry expert vs. non-industry expert

\begin{tabular}{|c|c|c|c|c|c|}
\hline \multirow[b]{2}{*}{ Variables a } & \multirow[b]{2}{*}{ Pred. Sign } & \multicolumn{2}{|c|}{ Industry expert } & \multicolumn{2}{|c|}{ Non-industry expert } \\
\hline & & Coefficient & $\mathrm{t}$-value $\mathrm{b}$ & Coefficient & t-value \\
\hline CONSTANT & & -3.7308 & $-3.41 * * *$ & -1.5807 & $-2.49 * *$ \\
\hline SCPA & + & 0.3056 & $2.96^{* * *}$ & 0.0076 & 0.11 \\
\hline GROWTH & + & 0.7330 & $5.09^{* * *}$ & 0.3369 & $3.58 * * *$ \\
\hline SIZE & $?$ & 0.1802 & $3.81^{* * *}$ & 0.0863 & $3.03 * * *$ \\
\hline LEV & - & 0.1002 & 0.18 & -0.4570 & $-1.31^{*}$ \\
\hline SRD & + & 0.9797 & $3.53^{* * *}$ & 1.0411 & $5.87 * * *$ \\
\hline AGE & $?$ & -0.0844 & -1.11 & 0.0697 & 1.59 \\
\hline FCF & + & 1.3531 & $2.81^{* * *}$ & 0.9776 & $3.20 * * *$ \\
\hline $\mathrm{RD}$ & + & 3.4096 & $4.43^{* * *}$ & 0.3739 & $2.09^{* *}$ \\
\hline YEAR & & Included & & Included & \\
\hline Adj. R2 & & $26.98 \%$ & & $20.48 \%$ & \\
\hline $\mathrm{n}$ & & 341 & & 618 & \\
\hline
\end{tabular}

${ }^{a}$ The definitions of the variables reported in this table are: $S C P A=1$ if a company hires supply chain auditors, else 0 ; $G R O W T H=$ one-year percentage increase in sales; $S I Z E=$ natural logarithm of total assets; $L E V=$ total long-term liabilities divided by total assets; $S R D=$ one minus the long-term investments plus fixed assets to total assets; $A G E=$ the natural $\log$ of one plus the number of years elapsed since the year of incorporation; $F C F=$ cash flow from operations minus cash dividends divided by total assets; $R D=$ research and development expense divided by sales.; YEAR = fiscal year dummies.

${ }^{\mathrm{b}}$ Asterisks *,**,*** indicate two-tailed significance at the $0.10,0.05$, and 0.01 levels, respectively. 
Table 5. Supply chain auditor of big 4 industry expert and firm value: consider audit rotation

\begin{tabular}{|c|c|c|c|c|c|}
\hline \multirow[b]{2}{*}{ Variables $^{\mathrm{a}}$} & \multirow[b]{2}{*}{ Pred. Sign } & \multicolumn{2}{|c|}{ Auditor tenure $>5$} & \multicolumn{2}{|c|}{ Auditor tenure $\leq 5$} \\
\hline & & Coefficient & $t$-value ${ }^{\mathrm{b}}$ & Coefficient & $t$-value \\
\hline CONSTANT & & -3.6474 & $-2.84 * * *$ & -2.4576 & -1.23 \\
\hline$S C P A$ & + & 0.3989 & $3.28 * * *$ & -0.0971 & -0.54 \\
\hline GROWTH & + & 0.6904 & $4.15^{* * *}$ & 0.9384 & $3.40 * * *$ \\
\hline SIZE & ? & 0.1809 & $3.32 * * *$ & 0.1236 & 1.41 \\
\hline$L E V$ & - & 0.3436 & 0.49 & 0.1924 & 0.25 \\
\hline$S R D$ & + & 1.1582 & $3.49^{* * *}$ & 0.6341 & $1.35^{*}$ \\
\hline$A G E$ & ? & -0.2326 & $-2.38 * *$ & 0.2569 & $2.28 * *$ \\
\hline$F C F$ & + & 1.5636 & $2.70 * * *$ & 0.6145 & 0.87 \\
\hline$R D$ & + & 3.5203 & $4.15^{* * *}$ & 0.0637 & 0.50 \\
\hline$Y E A R$ & & Included & & Included & \\
\hline Adj. $R^{2}$ & & $28.96 \%$ & & $23.11 \%$ & \\
\hline $\mathrm{n}$ & & 275 & & 66 & \\
\hline
\end{tabular}

${ }^{\text {a }}$ The definitions of the variables reported in this table are: $S C P A=1$ if a company hires supply chain auditors, else 0; GROWTH = one-year percentage increase in sales; $S I Z E=$ natural logarithm of total assets; $L E V=$ total long-term liabilities divided by total assets; $S R D=$ one minus the long-term investments plus fixed assets to total assets; $A G E=$ the natural log of one plus the number of years elapsed since the year of incorporation; $F C F=$ cash flow from operations minus cash dividends divided by total assets; $R D=$ research and development expense divided by sales.; YEAR $=$ fiscal year dummies.

${ }^{\mathrm{b}}$ Asterisks $*, * *, * * *$ indicate two-tailed significance at the $0.10,0.05$, and 0.01 levels, respectively.

To explore the relationship between supply chain auditors and firm value in different supply chain streams, we partitioned the sample into three subsamples: up-stream companies $(n=103)$, middle-stream companies $(n=44)$, and down-stream companies $(\mathrm{n}=128)$. Table 6 shows that $S C P A$ is only significant $(\mathrm{p}<0.05)$ in the up-stream subsample. One reason may be that market participants are impressed by the specific expertise and knowledge of up-stream supply chain auditors.

Sensitivity analysis was used to evaluate the robustness of our empirical results. We began by replicating the tests using Lang and Litzenberger's (1989) definition of firm value (TOBINSQ), as shown in Tables 3 and 4. Most of these empirical results are similar to those reported in the tables above. We then re-defined auditor industry specialization to partition the Big 4 sample and then re-estimate the regressions in Table 4. Our empirical results were unaffected by this alternative definition. Finally, we excluded the companies that changed their auditor. The results and conclusions remained unchanged.

Table 6. Consider different supply chain stream

\begin{tabular}{|c|c|c|c|c|c|c|c|}
\hline \multirow[b]{2}{*}{ Variables $^{\mathrm{a}}$} & \multirow[b]{2}{*}{ Pred. Sign } & \multicolumn{2}{|c|}{ Up-stream } & \multicolumn{2}{|c|}{ Middle- stream } & \multicolumn{2}{|c|}{ Down-stream } \\
\hline & & Coefficient & $t$-value ${ }^{\mathrm{b}}$ & Coefficient & $t$-value & Coefficient & $t$-value \\
\hline CONSTANT & & -7.4997 & $-3.30 * * *$ & 4.2478 & $2.87 * * *$ & -2.8921 & -1.23 \\
\hline$S C P A$ & + & 0.5553 & $1.94 * *$ & -0.1143 & -0.73 & 0.1791 & 1.29 \\
\hline GROWTH & + & 0.8497 & $2.55^{* * *}$ & 0.4896 & $2.56 * * *$ & 0.4996 & $2.50 * * *$ \\
\hline SIZE & $?$ & 0.3224 & $3.44 * * *$ & -0.1367 & $-2.28 * *$ & 0.1808 & $1.75^{*}$ \\
\hline$L E V$ & - & 1.5232 & 0.81 & 0.2998 & 0.48 & -0.3014 & -0.43 \\
\hline$S R D$ & + & 3.2594 & $4.65 * * *$ & 0.6009 & $1.67^{*}$ & -0.3602 & -0.96 \\
\hline$A G E$ & $?$ & -0.7056 & $-3.39 * * *$ & -0.4808 & $-2.76 * * *$ & 0.0946 & 0.92 \\
\hline$F C F$ & + & 1.7056 & $1.37 *$ & -1.5516 & -1.26 & 0.6401 & 1.09 \\
\hline$R D$ & + & 3.0947 & $2.07 * *$ & 2.8721 & 0.59 & 1.5339 & $1.29 *$ \\
\hline$Y E A R$ & & Included & & Included & & Included & \\
\hline Adj. $R^{2}$ & & $42.92 \%$ & & $55.00 \%$ & & $21.32 \%$ & \\
\hline $\mathrm{n}$ & & 103 & & 44 & & 128 & \\
\hline
\end{tabular}

\footnotetext{
${ }^{a}$ The definitions of the variables reported in this table are: $S C P A=1$ if a company hires supply chain auditors, else 0 ; GROWTH $=$ one-year percentage increase in sales; $S I Z E=$ natural logarithm of total assets; $L E V=$ total long-term liabilities divided by total assets; $S R D=$ one minus the long-term investments plus fixed assets to total assets; $A G E=$ the natural $\log$ of one plus the number of years elapsed since the year of incorporation; $F C F=$ cash flow from operations minus cash dividends divided by total assets; $R D=$ research and development expense divided by sales.; YEAR = fiscal year dummies.
}

${ }^{\mathrm{b}}$ Asterisks $*, * *, * * *$ indicate two-tailed significance at the $0.10,0.05$, and 0.01 levels, respectively. 


\section{Conclusions}

This study identified a positive relationship between the value of firms and specific features associated with supply chain auditors, including the size of the auditing firm, industry specialization, the tenure of the auditor, and the nature of the supply chain stream. Our results appear to support the conjecture that the selection of supply chain auditor can affect the value of the firm. These findings are important for two reasons. First, relatively little research has been performed to identify the effects of supply chain streams. From the perspective of investors, it is important to know that market participants consider supply chain auditors as a factor increasing firm value. Second, previous studies related to disclosures have provided empirical evidence that the tenure of auditors is related to the value of a firm; however, the results have been inconsistent. Our findings have important implications for regulators and policy-makers dealing with debate on mandatory rotation.

\section{References}

Balsam, S., Krishnan, J., \& Yang, J. S. (2003). Auditor industry specialization and earnings quality. Auditing: A Journal of Practice and Theory, 22(2), 71-97. http://dx.doi.org/10.2308/aud.2003.22.2.71

Becker, C., DeFond, M., Jiambalvo, J., \& Subramanyam, K. R. (1998). The effect of audit quality on earnings management. Contemporary Accounting Research, 15(1), 1-24. http://dx.doi.org/10.1111/j.1911-3846.1998.tb00547.x

Boone, J. P., Khurana, I. K., \& Raman, K. K. (2008). Audit firm tenure and the equity risk premium. Journal of Accounting, Auditing, and Finance, 23(1), 115-140.

Chin, C. L., \& Chi, H. Y. (2009). Reducing restatement with increased industry expertise. Contemporary Accounting Research, 26(3), 729-765. http://dx.doi.org/10.1506/car.26.3.4

Davis, L. R., Soo, B. S., \& Trompeter, G. M. (2009). Auditor tenure and the ability to meet or beat earnings forecasts. Contemporary Accounting Research, 26(2), 517-548. http://dx.doi.org/10.1506/car.26.2.8

Dang, L. (2004). Assessing Actual Audit Quality. Unpublished doctoral dissertation, Drexel University, Philadelphia, PA.

Francis, J., LaFond, R., Olsson, P., \& Schipper, K. (2005). The market pricing of accruals quality. Journal of Accounting and Economics, 39(2), 295-327. http://dx.doi.org/10.1016/j.jacceco.2004.06.003

Francis, J. R. (2004). What do we know about audit quality? The British Accounting Review, 36(4), 345-368. http://dx.doi.org/10.1016/j.bar.2004.09.003

Francis, J., Maydew, E., \& Sparks, H. (1999). The role of big 6 auditors in the credible reporting of accruals. Auditing: A Journal of Practice and Theory, 18(2), 17-34. http://dx.doi.org/10.2308/aud.1999.18.2.17

Ghosh, A., \& Moon, D. (2005). Auditor tenure and perceptions of audit quality. The Accounting Review, 80(2), 585-612. http://dx.doi.org/10.2308/accr.2005.80.2.585

Gramling, A. A., \& Stone, D. N. (2001). Audit firm industry expertise: A review and synthesis of the archival literature. Journal of Accounting Literature, 20, 1-29.

Gul, F. A., Fung, S. Y. K., \& Jaggi, B. (2009). Earnings quality: Some evidence on the role of auditor tenure and auditors' industry expertise. Journal of Accounting and Economics, 47(3), 265-287. http://dx.doi.org/10.1016/j.jacceco.2009.03.001

Jeong, S. W., \& Rho, J. (2004). Big six auditors and audit quality: The Korean evidence. The International Journal of Accounting, 39(2), 175-196. http://dx.doi.org/10.1016/j.intacc.2004.02.001

Johnstone, K. M., Bedard, J. C., \& Biggs, S. F. (2002). Aggressive client reporting: Factors affecting auditors' generation of financial reporting alternatives. Auditing: A Journal of Practice \& Theory, 21(1), 47-65. http://dx.doi.org/10.2308/aud.2002.21.1.47

Kabir, M. H., Sharma, D., Islam, M. A., \& Salat, A. (2010). Big 4 auditor affiliation and accruals quality in Bangladesh. Managerial Auditing Journal, 26(2), 161-181. http://dx.doi.org/10.1108/02686901111095029

Knechel, W. R., Naiker, V., \& Pacheko, G. (2007). Does auditor industry specialization matter? Evidence from market reaction to auditor switches. Auditing: A Journal of Practice \& Theory, 26(1), 19-45. http://dx.doi.org/10.2308/aud.2007.26.1.19

Krishnan, G. V. (2003). Does big 6 auditor industry expertise constrain earnings management? Accounting Horizons, 17(Supplement), 1-16. http://dx.doi.org/10.2308/acch.2003.17.s-1.1

Lang, L. H. P., \& Litzenberger, R. H. (1989). Dividend announcements: Cash flow signaling vs. free cash flow 
hypothesis. Journal of Financial $181-192$. http://dx.doi.org/10.1016/0304-405X(89)90077-9

Mansi, A., Maxwell, F., \& Miller, P. (2004). Does auditor quality and tenure matter to investors? Evidence from the bond market. Journal of Accounting Research, 42(4), $755-793$. http://dx.doi.org/10.1111/j.1475-679X.2004.00156.x

Myers, J. N., Myers, L. A., \& Skinner, D. J. (2007). Earnings momentum and earnings management. Journal of Accounting, Auditing and Finance, 22(2), 249-284. http://dx.doi.org/10.2139/ssrn.741244

Myers, J. N., Myers, L. A., \& Omer, T. C. (2003). Exploring the term of the auditor-client relationship and quality of earnings: A case for mandatory auditor rotation? The Accounting Review, 78(3), 779-799. http://dx.doi.org/10.2308/accr.2003.78.3.779

Owhoso, V. E., Messier, W. F., \& Lynch, J. G. (2002). Error detection by industry-specialized teams during sequential audit review. Journal of Accounting Research, 40(3), 883-900. http://dx.doi.org/10.1111/1475-679X.00075

Palmrose, Z. V. (1988). An analysis of auditor litigation and audit service quality. The Accounting Review, 63(1), $55-73$.

Reichelt, K. J., \& Wang, D. (2010). National and office-specific measures of auditor industry expertise and effects on audit quality. Journal of Accounting Research, 48(3), 647-686. http://dx.doi.org/10.1111/j.1475-679X.2009.00363.x

Solomon, I., Shields, M. D., \& Whittington, O. R. (1999). What do industry-specialist auditors know? Journal of Accounting Research, 37(1), 191-208. http://dx.doi.org/10.2307/2491403

Teoh, S. H., \& Wong, T. J. (1993). Perceived auditor quality and the earnings response coefficient. The Accounting Review, 68(2), 346-366.

\section{Copyrights}

Copyright for this article is retained by the author(s), with first publication rights granted to the journal.

This is an open-access article distributed under the terms and conditions of the Creative Commons Attribution license (http://creativecommons.org/licenses/by/3.0/). 